\title{
Nota
}

\section{PHOSPHORUS AVAILABILITY IN OXIDIC SOILS TREATED WITH LIME AND SILICATE APPLICATIONS ${ }^{(1)}$}

\author{
Aline da Silva Sandim ${ }^{(2)}$, Leonardo Theodoro Büll ${ }^{(3)}$, Ariane Reis Furim ${ }^{(4)}$, Géssica da \\ Silva Lima ${ }^{(5)}$ \& Jader Luis Nantes Garcia ${ }^{(5)}$
}

\begin{abstract}
SUMMARY
Based on the assumption that silicate application can raise soil $\mathrm{P}$ availability for crops, the aim of this research was to compare the effect of silicate application on soil P desorption with that of liming, in evaluations based on two extractors and plant growth. The experiment was carried out in randomized blocks with four replications, in a $3 \times 3 \times 5$ factorial design, in which three soil types, three $P$ rates, and four soil acidity correctives were evaluated in 180 experimental plots. Trials were performed in a greenhouse using corn plants in $20-\mathrm{dm}^{3}$ pots. Three $P$ rates $(0$, 50 and $150 \mathrm{mg} \mathrm{dm}^{-3}$ ) were applied in the form of powder triple superphosphate and the soil was incubated for 90 days. After this period, soil samples were collected for routine chemical analysis and $P$ content determination by the extraction methods resin, Mehlich-1 and remaining $P$. Based on the results, acidity correctives were applied at rates calculated for base saturation increased to $70 \%$, with subsequent incubation for 60 more days, when $P$ content was determined again. The acidity correctives consisted of: dolomitic lime, steelmaking slag, ladle furnace slag, and wollastonite. Therefore, our results showed that slags raised the soil $\mathbf{P}$ content more than lime, suggesting a positive correlation between $\mathrm{P}$ and $\mathrm{Si}$ in soil. Silicon did not affect the extractor choice since both Mehlich-1 and resin had the same behavior regarding extracted $P$ when silicon was applied to the soil. For all evaluated plant parameters, there was significant interaction between $P$ rates and correctives; highest values were obtained with silicate.
\end{abstract}

Index terms: phosphorus adsorption, silicate application, liming, silicon- phosphorus interaction.

\footnotetext{
(1) Part of the Master's Thesis of the first author. Research funded by CNPq. Received for publication on August 12,2013 and approved on April 28, 2014.

(2) Doctoral student in Agronomy, College of Agricultural Sciences - CAS, University of São Paulo State (Universidade do Estado de São Paulo) - UNESP. Lageado Experimental Farm. Rua José Barbosa de Barros, 1780. Caixa Postal 237. CEP 18610-307 Botucatu (SP), Brazil. E-mail: alinesandim@gmail.com

(3) Full Professor, CAS - UNESP. E-mail: bull@fca.unesp.br

(4) Agronomy student, CAS - UNESP. E-mail: arfurin@fca.unesp.br

(5) Master student in Agronomy, CAS - UNESP. E-mail: gessicaslima@hotmail.com, jader_nantes@hotmail.com
} 


\title{
RESUMO: DISPONIBILIDADE DE FÓSFORO EM RAZÃO DA APLICAÇÃO DE CALCÁRIO E SILICATOS EM SOLOS OXÍDICOS
}

\begin{abstract}
Partindo do princípio que a aplicação do silicato pode resultar em aumento na disponibilidade de P no solo para as culturas, objetivou-se estudar a influência da silicatagem, em comparação à calagem, na dessorção de $\mathrm{P}$ em solos, avaliada por dois extratores e pelo crescimento da planta. O delineamento experimental utilizado foi em blocos casualizados, com quatro repetições, em esquema fatorial $3 \times 3 \times 5$, constituído por três solos, três doses de $P$ e quatro corretivos de acidez, além de um tratamento sem correção da acidez, totalizando 180 parcelas experimentais. O experimento foi realizado em casa de vegetação, em vasos de $20 \mathrm{dm}^{3}$. Os solos foram submetidos a três doses de $P\left(0,50\right.$ e $\left.150 \mathrm{mg} \mathrm{dm}^{-3}\right)$, tendo como fonte superfosfato triplo em pó e mantidos incubados por 90 dias. Após o período de incubação, foram realizadas amostragens para análise química de rotina e determinações dos teores de $P$ pelos métodos resina, Mehlich-1 e Premanescente. Com base nesses resultados, foi realizada a aplicação dos corretivos de acidez com as doses calculadas a fim de elevar a $70 \%$ o valor de saturação por bases, permanecendo incubados por mais 60 dias; após, novas determinações dos teores de $P$ foram realizadas. Os corretivos de acidez utilizados foram: calcário dolomítico, escória de aciaria, escória forno de panela e wollastonita. A cultura utilizada foi a do milho. Com os resultados, observou-se que as escórias aumentaram os teores de P no solo, quando comparadas ao calcário, sugerindo a interação positiva entre Si e P no solo. O uso do Si não interferiu na escolha do extrator, pois tanto o Mehlich-1 como a resina apresentaram o mesmo comportamento, quando houve a adição de Si ao solo em relação ao P extraído. Para todos os parâmetros analisados na planta, houve interação significativa entre as doses de Pe os corretivos utilizados, com maiores valores com o uso de silicatos.
\end{abstract}

Termos de indexação: adsorção de fósforo, silicatagem, calagem, interação silício-fósforo.

\section{INTRODUCTION}

The reaction of phosphate ion adsorption to soil colloids is directly related to the reaction conditions of soil, since with a rise of $\mathrm{pH}$ the solubility of iron and aluminum phosphates is increased with reduction of phosphate anion adsorption to the soil solid phase. As an alternative technique for soil acidity correction, calcium silicate $\left(\mathrm{CaSiO}_{3}\right)$ can be used, with a similar reaction to that of lime which, in addition to raising the $\mathrm{pH}$, makes $\mathrm{H}_{3} \mathrm{SiO}_{4}$ available. This silicate anion competes with phosphate anions for the same adsorption site, thus saturating sites where $\mathrm{P}$ could be adsorbed.

Studies addressing $\mathrm{P}$ availability under acidic conditions, chemical determinations such as maximum P adsorption (Vasconcellos et al., 1974, Gonçalves et al., 1985), adsorption energy (Ernani et al., 1996), and extractors (Novais et al., 2007) agree on the great influence of soil acidity and chemical changes of $\mathrm{P}$ in soil caused by precipitation/adsorption reactions.

The extractor Mehlich-1, widely used in routine laboratory analyses across the country, may overestimate available $\mathrm{P}$ contents in soils treated with rock phosphate, or in situations where inorganic $\mathrm{Ca}$ $\mathrm{P}$ contents are higher due to low weathering (Novelino et al., 1985). This extractor may also underestimate available $\mathrm{P}$ in soils with high clay content, due to the resulting extractor wear (Novais \& Kamprath, 1979, Muniz et al., 1987). However, the resin method is also questionable due to the likely underestimation of labile
$\mathrm{P}$, especially in soils with high $\mathrm{P}$ adsorption capacity (Campello et al., 1994; Schlindwein \& Gianello, 2008).

Assuming that silicate application may increase the soil $\mathrm{P}$ availability for crops, because the silicate anion occupies sites of phosphate anion adsorption, the objective of this study was to evaluate the influence of silicate application compared to liming on $\mathrm{P}$ desorption, in soils with previously adsorbed $\mathrm{P}$, assessed by two extractors and plant growth.

\section{MATERIAL AND METHODS}

The experiment was carried out in a greenhouse in an experimental area of the Soil and Natural Resources Department, College of Agricultural Sciences of the São Paulo State University (UNESP) in Botucatu, SP. Three soils were incubated with P, subsequently treated with correctives and corn was grown.

Three oxidic soils of different textural classes, all acid, with low contents of labile $\mathrm{P}$, organic matter and silicon were classified according to Embrapa (2006) as dystrophic Typic Quartzipsamment (Entisols) with sandy texture (RQ), dystroferric Rhodic Hapludox (Oxisols) with clayey texture (Lvd), and dystrophic Rhodic Hapludox (Oxisols) with medium texture (LVd) (Table 1). Surface samples $(0-20 \mathrm{~cm}$ depth) were collected for chemical analysis to determine resin $\mathrm{P}$, Mehlich-1, remaining $\mathrm{P}$ by the technique proposed by Alvarez V. et al. (2000), and the Si content (Table 1). 
Table 1. Chemical characteristics of the studied soils

\begin{tabular}{|c|c|c|c|c|c|c|c|c|c|c|c|c|c|c|c|c|c|c|}
\hline Soil & $\mathrm{pH}\left(\mathrm{CaCl}_{2}\right)$ & OM & $P_{\text {resin }}$ & $\mathbf{P}_{\text {Mehlich }}$ & $P_{\text {rem }}$ & $\mathrm{Al}^{3+}$ & $\mathrm{H}+\mathrm{Al}$ & $\mathbf{K}$ & $\mathrm{Ca}$ & Mg & SB & CEC & $\mathrm{V}$ & $\mathrm{S}$ & $\mathrm{Si}\left(\mathrm{CaCl}_{2}\right)$ & Clay & Sand & Silt \\
\hline & & $\mathrm{g} \mathrm{dm}^{-3}$ & . & $-\mathrm{mg} \mathrm{dm} \mathrm{m}^{-3}$ & 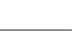 & & 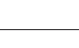 & & $l_{c} \mathrm{dm}$ & & & {[} & $\%$ & $-\mathrm{m}$ & $g \mathrm{dm}^{-3}-$ & & $\mathrm{g} \mathrm{kg}^{-1}$ & \\
\hline Lvd & 4.1 & 37 & 5 & 1.5 & 9 & 15 & 71 & 1.0 & 5 & 2 & 9 & 79 & 11 & 26 & 1.2 & 584 & 163 & 253 \\
\hline LVd & 4.0 & 30 & $T$ & 1.2 & 19 & 19 & 67 & 0.3 & 3 & 1 & 4 & 71 & 6 & 26 & 3.1 & 274 & 669 & 57 \\
\hline $\mathrm{RQ}$ & 4.3 & 11 & $\operatorname{Trç}$ & 1 & 41 & 4 & 24 & 0.7 & 2 & 1 & 4 & 28 & 15 & 7 & 1.2 & 135 & 802 & 63 \\
\hline
\end{tabular}

Lvd: dystroferric Rhodic Hapludox (Oxisols); LVd: dystrophic Rhodic Hapludox (Oxisols); RQ: dystrophic Typic Quartzipsamment (Entisol).

Thereafter, each soil was subjected to three $\mathrm{P}$ rates (0; 50; and $150 \mathrm{mg} \mathrm{dm}^{-3}$ ), applied in the $\mathrm{P}$ source powder triple superphosphate, saturated to $70 \%$ of the maximum water holding capacity, and incubated for 90 days for adsorption.

After incubation, samples for routine chemical analysis and new determinations of the amounts of $\mathrm{P}$ through resin, Mehlich-1, and remaining $\mathrm{P}\left(\mathrm{P}_{\text {rem }}\right)$ were performed. Based on these results, acidity corrective applications were performed and rates were calculated to raise base saturation to $70 \%$ (Raij et al., 1996).

The correctives applied were dolomitic lime (DL), steelmaking slag (SS), ladle furnace slag (LFS) and wollastonite (W). Then, soil moisture was maintained at $70 \%$ of the maximum water holding capacity, and incubated for 60 days. This incubation period was used to ensure that the reaction of silicates with the soil was complete, due to the low RPTN (Relative Power of Total Neutralization) of these correctives (Table 2), analyzed according to the method proposed by Alcarde (2009).

After the reaction period, $\mathrm{P}$ determination was repeated and then other nutrients were applied at equal amounts in all treatments: $120 \mathrm{mg} \mathrm{dm}^{-3} /$ pot of $\mathrm{K}$ (as $\mathrm{KCl}$ ), $60 \mathrm{mg} \mathrm{dm}^{-3} /$ pot of $\mathrm{N}$ (as ammonium sulfate), and $2 \mathrm{~g} /$ pot micronutrients $\mathrm{B}, \mathrm{Zn}, \mathrm{Cu}, \mathrm{Fe}, \mathrm{Mn}$ (as silicate oxides).

Five corn seeds per pot were sown, thinned to two plants 15 days after emergence, and left to grow for 60 days until harvest. During crop growth, irrigation was performed daily based on a Class A tank and crop evapotranspiration data, aside from biweekly applications of $30 \mathrm{mg} \mathrm{dm}^{-3} \mathrm{~N}$ in solution, and soil moisture was maintained at $70 \%$ water holding capacity.

The experiment was arranged in a completely randomized factorial design $(3 \times 3 \times 5)$ with three soils (RQ, Lvd, and LVd), three $\mathrm{P}$ rates $(0,50$, and $150 \mathrm{mg} \mathrm{dm}^{-3}$ ), four acidity correctives (DL, SS, LFS, and $\mathrm{W}$ ), and one control treatment (without acidity correction) in four replications, i.e., a total of 180 experimental units. Each experimental unit consisted of a plastic pot containing $20 \mathrm{dm}^{3}$ soil and two corn plants.

Soil was sampled from the pots with an auger sampler, at the end of the incubation period with $\mathrm{P}$ and acidity correctives. The $\mathrm{pH}$ was determined in $\mathrm{CaCl}_{2}$; the $\mathrm{P}, \mathrm{Ca}, \mathrm{Mg}$, and $\mathrm{K}$ contents by ion exchange resin extraction; and $\mathrm{H}+\mathrm{Al}$ by calcium acetate (Raij et al., 2001); $\mathrm{Si}$; and remaining $\mathrm{P}$ were performed in the samples. Additionally, the $\mathrm{P}$ content was determined by Mehlich-1.

Sixty days after corn emergence, at the time of harvest, the dry matter weight, plant height, stem diameter, and $\mathrm{P}$ accumulation were determined in the laboratory.

The stem diameter was measured $1 \mathrm{~cm}$ above the ground with a digital caliper and plant height with a millimeter ruler.

The corn plants were harvested and separated into roots and shoots. Subsequently, they were washed and dried in a forced air oven at $65^{\circ} \mathrm{C}$ to constant weight (shoot dry matter - SDM); and after weighing, ground in a Willey mill and mineralized by sulphuric digestion (Tedesco et al., 1995), determining the $\mathrm{P}$ concentration by the method described by Malavolta et al. (1997).

Data were subjected to variance analysis, the means compared by Tukey's test at $5 \%$, using SISVAR software. The effects of $\mathrm{P}$ rates were tested by means of regression equations. Regression models were selected based on the $\mathrm{F}$ test, at 1 and $5 \%$, with their respective determination coefficients.

\section{RESULTS AND DISCUSSION}

Comparing the silicates and lime, wollastonite was most efficient in raising the $\mathrm{pH}$ in sandy and mediumtextured soils. The lime and ladle furnace slag had a similar behavior, which can be explained by the similarity in reactivity and RPTN of these products. In contrast, the same was not true for steelmaking slag, which had lower $\mathrm{pH}$ values than the other correctives; this fact can be explained by the larger grain size and, consequently, the longer time required for reaction (Table 3).

In sandy soil, wollastonite differed from the other correctives, with greater ability to correct $\mathrm{pH}$. However, in this soil, $\mathrm{pH}$ values were lower than in the other soils, in disagreement with Deus (2010), who found higher $\mathrm{pH}$ values in sandy soil compared to two 
soils with higher clay contents under liming and silicate application. According to Assis et al. (2007), this fact may be related to the low buffering capacity of the sandy soils, in which the effect of the corrective decreases when $\mathrm{pH}$ reaches high values (Table 3).

Analyzing the effect of $\mathrm{P}$ separately (Table 4), it was found that $\mathrm{P}$ rates increased the content of $\mathrm{P}$ extracted by resin in all soils; a significant interaction between corrective application and $\mathrm{P}$ rates was stated.

It was noted that lime raised the $\mathrm{P}$ contents at the highest $\mathrm{P}$ rate more than wollastonite in the Quartzipsamment. Differently, in Rhodic Hapludox soils, steelmaking slag increased soil $\mathrm{P}$ content, which can be explained by $\mathrm{pH}$ increase and the interaction with silicate anions, which when adsorbed to the soil solid phase, compete for the same sites with $\mathrm{P}$, hindering its adsorption and, consequently, increasing P in soil solution (Obihara \& Russell, 1972). Thus, correction of soil acidity with silicates, besides raising the $\mathrm{pH}$, increased $\mathrm{P}$ availability by

Table 2. Chemical analysis of acidity correctives: dolomitic lime (DL), ladle furnace slag (LFS), wollastonite (W) and steelmaking slag (SS)

\begin{tabular}{ccccc}
\hline Characteristic & DL & LFS & W & SS \\
\hline & \multicolumn{5}{c}{ g kg-1 $^{-1}$} \\
\cline { 2 - 5 } $\mathrm{Ca}$ & 277 & 274 & 262 & 216 \\
$\mathrm{Mg}$ & 164.0 & 15.6 & 13.1 & 15.6 \\
$\mathrm{Si}$ & 80.0 & 121.0 & 168.2 & 90.08 \\
$\mathrm{P}_{2} \mathrm{O}_{5}$ & $\mathrm{trç}$ & 2.5 & 1.5 & 1.1 \\
$\mathrm{~K}_{2} \mathrm{O}$ & 0.5 & 0.3 & 0.1 & 0.3 \\
& & & \\
$\mathrm{~B}$ & 200 & 300 & 100 & 900 \\
$\mathrm{Cu}$ & 50 & 20 & 10 & 30 \\
$\mathrm{Fe}$ & 3900 & 28600 & 600 & 193500 \\
$\mathrm{Mn}$ & 800 & 3700 & 50 & 21500 \\
$\mathrm{Zn}$ & 10 & 50 & 40 & 70 \\
& & & & \\
$\mathrm{NP}$ & 84 & 77 & 60 & 70 \\
$\mathrm{RE}$ & 68 & 80 & 100 & 71 \\
$\mathrm{TNRP}$ & 58 & 62 & 60 & 50 \\
\hline
\end{tabular}

transferring adsorbed $\mathrm{P}$ to the soil solution (Volkweiss \& Raij, 1977).

The highest $\mathrm{P}$ content in treatments with silicates can be attributed to the sum of two effects: the alkalizing power of $\mathrm{Si}$ and competition for the same site between $\mathrm{Si}$ and P. Silicate application resulted in a trend of declining adsorption, which was lower at the higher P rates. Roy et al. (1971), who studied Si application prior to phosphate fertilization, as similarly done with liming, in Ca or $\mathrm{Mg}$ silicate form at high rates, increased $\mathrm{P}$ availability; this fact may have been more influenced by $\mathrm{pH}$ increase than by competition for the same adsorption site between $\mathrm{Si}$ and P. In this study, $\mathrm{P}$ rates were applied prior to the correctives for the occurrence of adsorption and, subsequently, the ability of silicates to desorb previously fixed $\mathrm{P}$ was checked.

The use of Ca silicate $\left(\mathrm{CaSiO}_{3}\right)$ and/or $\mathrm{Mg}$ silicate $\left(\mathrm{MgSiO}_{3}\right)$ as soil acidity correctives, instead of $\mathrm{CaCO}_{3}$, may be recommended due to possible competition for the same adsorption site between $\mathrm{Si}$ and $\mathrm{P}$, which reduces $\mathrm{P}$ fixation and allows greater $\mathrm{P}$ availability in the soil (Carvalho et al., 2000).

The $\mathrm{P}$ recovery capacity of the two extractors was different, since the resin extracted more $\mathrm{P}$ than Mehlich-1 (Table 4). This can be explained by the action of the resin which is similar to that of plant roots, i.e., quantifying labile $\mathrm{P}$ as well, while Mehlich-1 extractor, for being acid, has the ability to extract from soil $\mathrm{P}$ forms linked especially to $\mathrm{Ca}$, which would not be readily available to plants. In general, the amount of $\mathrm{P}$ derived by the two methods varied in relative terms, depending on $P$ rates applied. Although they differ in extraction ability, the use of various methods for $\mathrm{P}$ analysis leads to non-comparable results in absolute values due to the influence of particular conditions related to each technique (Raij, 1978; Silva \& Braga, 1992).

Table 4 shows that in clayey soil $\mathrm{P}$ contents were lower than in the Quartzipsamment soil, indicating that this extractor ability decreases in clayey soils due to the consumption of hydrogen ions by functional groups not occupied by $\mathrm{P}$ in inorganic colloids and resorption of $\mathrm{P}$ to colloids during extraction.

Assessing the efficiency of Mehlich-1 and anion exchange resin in the quantification of available $\mathrm{P}$ for

Table 3. Soil pH under corrective applications

\begin{tabular}{|c|c|c|c|c|c|c|}
\hline Soil & No application & Dolomitic lime & Wollastonite & Ladle furnace slag & Steelmaking slag & CV \\
\hline & & & & & & $\%$ \\
\hline RQ & $4.1 \mathrm{c}$ & $5.3 \mathrm{ab}$ & $5.5 \mathrm{a}$ & $5.4 \mathrm{ab}$ & $5.2 \mathrm{~b}$ & 2.9 \\
\hline $\mathrm{LVd}$ & $4.0 \mathrm{~d}$ & $5.7 \mathrm{~b}$ & $5.9 \mathrm{a}$ & $5.6 \mathrm{~b}$ & $5.4 \mathrm{c}$ & 2.8 \\
\hline Lvd & $4.0 \mathrm{c}$ & $5.7 \mathrm{a}$ & $5.8 \mathrm{a}$ & $5.7 \mathrm{a}$ & $5.5 \mathrm{~b}$ & 2.0 \\
\hline
\end{tabular}

Lvd: dystroferric Rhodic Hapludox (Oxisols); LVd: dystrophic Rhodic Hapludox (Oxisols); RQ: dystrophic Typic Quartzipsamment (Entisol). Means followed by lower-case letters in the same row differ statistically by Tukey's test at $1 \%$. 
Table 4. Soil $P$ content, extracted by the resin method and by Mehlich-1, after application of correctives (dolomitic lime - DL, ladle furnace slag - LFS, wollastonite - W, steelmaking slag - SS) and P rates

\begin{tabular}{|c|c|c|c|c|c|c|c|c|c|c|}
\hline \multirow{2}{*}{ Rate } & \multicolumn{4}{|c|}{$P$ resin } & \multirow[b]{2}{*}{ SS } & \multicolumn{5}{|c|}{ P Mehlich } \\
\hline & No correction & DL & W & LFS & & No correction & DL & W & LFS & SS \\
\hline & \multicolumn{10}{|c|}{$\mathrm{mg} \mathrm{dm}^{-3}$} \\
\hline 0 & $2.6 \mathrm{a}$ & $2.7 \mathrm{a}$ & $4.8 \mathrm{a}$ & $3.2 \mathrm{a}$ & $5.5 \mathrm{a}$ & 0.7 & 1.2 & 1.3 & 1.0 & 1.6 \\
\hline 50 & $20.7 \mathrm{a}$ & $23.4 \mathrm{a}$ & $26.3 \mathrm{a}$ & $20.8 \mathrm{a}$ & $26.7 \mathrm{a}$ & $6.9 \mathrm{~b}$ & $10.1 \mathrm{a}$ & $9.4 \mathrm{a}$ & $9.3 \mathrm{a}$ & $11.5 \mathrm{a}$ \\
\hline 150 & $66.6 \mathrm{~d}$ & $79.1 \mathrm{a}$ & $68.8 \mathrm{~cd}$ & $76.0 \mathrm{ab}$ & $73.6 \mathrm{abc}$ & $16.5 \mathrm{e}$ & $31.3 \mathrm{~b}$ & $19.5 \mathrm{c}$ & $34.9 \mathrm{a}$ & $17.5 \mathrm{~cd}$ \\
\hline Effect & $\mathrm{L}^{(1) * *}$ & $\mathrm{Q}^{(2) *}$ & $\mathrm{~L}^{* *}$ & $\mathrm{Q}^{* *}$ & $\mathrm{~L}^{* *}$ & $L^{* *}$ & $\mathrm{~L}^{* *}$ & $\mathrm{Q}^{* *}$ & $\mathrm{Q}^{* *}$ & $\mathrm{Q}^{* *}$ \\
\hline \multirow[t]{2}{*}{ CV (\%) } & 13.19 & & & & & 9.58 & & & & \\
\hline & & \multicolumn{9}{|c|}{ Medium-textured soil (LVd) } \\
\hline 0 & $2.8 \mathrm{~b}$ & $3.3 \mathrm{~b}$ & $3.5 \mathrm{~b}$ & $4.2 \mathrm{~b}$ & $15.0 \mathrm{a}$ & 0.9 & 1.6 & 0.9 & 1.2 & 2.2 \\
\hline 50 & $19.0 \mathrm{~d}$ & $26.5 \mathrm{~b}$ & $20.4 \mathrm{~cd}$ & $22.4 \mathrm{c}$ & $35.0 \mathrm{a}$ & 5.1 & 5.3 & 5.1 & 6.1 & 6.6 \\
\hline 150 & $59.7 \mathrm{~d}$ & $68.0 \mathrm{c}$ & $65.8 \mathrm{c}$ & $71.8 \mathrm{~b}$ & $76.3 \mathrm{a}$ & $14.9 \mathrm{~b}$ & $19.2 \mathrm{ab}$ & $16.2 \mathrm{ab}$ & $17.5 \mathrm{ab}$ & $21.8 \mathrm{a}$ \\
\hline Effect & $Q^{* *}$ & $\mathrm{Q}^{* *}$ & $\mathrm{Q}^{* *}$ & $\mathrm{Q}^{* *}$ & $\mathrm{~L}^{* *}$ & $\mathrm{~L}^{* *}$ & $\mathrm{~L}^{* *}$ & $\mathrm{~L}^{* *}$ & $\mathrm{~L}^{* *}$ & $\mathrm{~L}^{* *}$ \\
\hline \multirow[t]{2}{*}{ CV (\%) } & 3.55 & & & & & 24.12 & & & & \\
\hline & & \multicolumn{9}{|c|}{ Clayey soil (Lvd) } \\
\hline 0 & $4.8 \mathrm{~b}$ & $5.7 \mathrm{~b}$ & $6.3 \mathrm{~b}$ & $6.0 \mathrm{~b}$ & $17.8 \mathrm{a}$ & 0.5 & 1.1 & 1.1 & 0.6 & 2.2 \\
\hline 50 & $22.6 \mathrm{~b}$ & $24.2 \mathrm{~b}$ & $26.5 \mathrm{~b}$ & $26.0 \mathrm{~b}$ & $34.1 \mathrm{a}$ & 2.6 & 3.1 & 3.5 & 3.6 & 4.0 \\
\hline 150 & $54.4 \mathrm{~d}$ & $77.2 \mathrm{~b}$ & $64.6 \mathrm{c}$ & $63.2 \mathrm{c}$ & $82.8 \mathrm{a}$ & $10.5 \mathrm{~b}$ & $11.6 \mathrm{~b}$ & $11.2 \mathrm{~b}$ & $11.6 \mathrm{~b}$ & $15.0 \mathrm{a}$ \\
\hline Effect & $\mathrm{L}^{* *}$ & $Q^{* *}$ & $\mathrm{~L}^{* *}$ & $\mathrm{~L}^{* *}$ & $\mathrm{Q}^{* *}$ & $\mathrm{~L}^{* *}$ & $Q^{*}$ & $\mathrm{Q}^{*}$ & $\mathrm{~L}^{* *}$ & $Q^{* *}$ \\
\hline CV (\%) & 5.92 & & & & & 16.07 & & & & \\
\hline
\end{tabular}

(1) Q: quadratic effect; ${ }^{(2)}$ L: linear effect. Lvd: dystroferric Rhodic Hapludox (Oxisols); LVd: dystrophic Rhodic Hapludox (Oxisols); RQ: dystrophic Typic Quartzipsamment (Entisol). Means followed by lower case letters in the same row differ statistically by Tukey's test at $1 \%$. ${ }^{*}$ and $* *$ significant at 5 and $1 \%$, respectively.

castor bean plants in a greenhouse, Brito Neto (2011) noted that Melich-1 was more efficient in extracting $\mathrm{P}$ than ion exchange resin, regardless of the applied rate, which disagrees with the findings of this study. Notwithstanding, a higher or lower $\mathrm{P}$ recovery is no indicator of the extractor quality, but rather of how the extracted quantities are related to plant uptake. This behavior can be explained by the fact that in Northeastern Brazil, where the above study was carried out, soils are less acidic than in other regions of the country, favoring the formation of poorly soluble compounds of calcium phosphate (Ca-P); in those soils, $\mathrm{Ca}^{2+}$ contents are high and $\mathrm{pH}$ near neutrality.

It was observed that silicon application did not interfere with the extractor choice, since Mehlich-1 as well as extractor resin had a similar behavior when Si was added to the soil in relation to extracted $P$.

In terms of $\mathrm{P}$ content and accumulation in plant, dry matter increased significantly (Table 5). Polynomial regressions showed, for all correctives, that element contents and accumulation in the plant responded to increasing rates according to quadratic and linear equations and were considerably higher for the clayey soil.

In the sandy soil, plant $\mathrm{P}$ contents were lower compared to the others, with decreased $\mathrm{P}$ content at the highest $\mathrm{P}$ rate. This may have occurred due to the dilution effect within the plant, since this soil promoted greater plant growth. Among the correctives, steelmaking slags resulted in higher $\mathrm{P}$ content in plants without $\mathrm{P}$ addition, i.e., at zero rate, while at the other rates when lime was used, the $\mathrm{P}$ contents were higher. These values were clearly higher than the 1.00 and $1.20 \mathrm{~g} \mathrm{~kg}^{-1}$ obtained by Camargo (2009) in corn plants, who evaluated steelmaking slag as soil acidity corrective and its effect on $\mathrm{P}$ availability applied to a Rhodic Hapludox soil.

In medium-textured soil, it was observed that $\mathrm{P}$ content and accumulation values were lower than in the sandy soil, except when steelmaking slag was used at the lowest and highest $\mathrm{P}$ rates, demonstrating a possible interaction between $\mathrm{Si} \times \mathrm{P}$ (Table 5). In clayey soil, a higher $\mathrm{P}$ content and accumulation values for corn plants were observed. Again, the results of steelmaking slag were better than of the other corrective both for content and accumulation, which in this soil was highest at all $\mathrm{P}$ rates; the maximum accumulated value was $255.42 \mathrm{~g} /$ pot. In this case, the interaction between $\mathrm{Si} \times \mathrm{P}$ in the soil is suggested even more than the $\mathrm{pH}$ increase.

To evaluate the chemical changes resulting from thermophosphate application to cerrado (savannahlike vegetation) soil and agronomic efficiency of 
Table 5. Phosphorus content and $P$ accumulation in corn plants after application of correctives (dolomitic lime - DL, ladle furnace slag - LFS, wollastonite - W, steelmaking slag - SS) and P rates

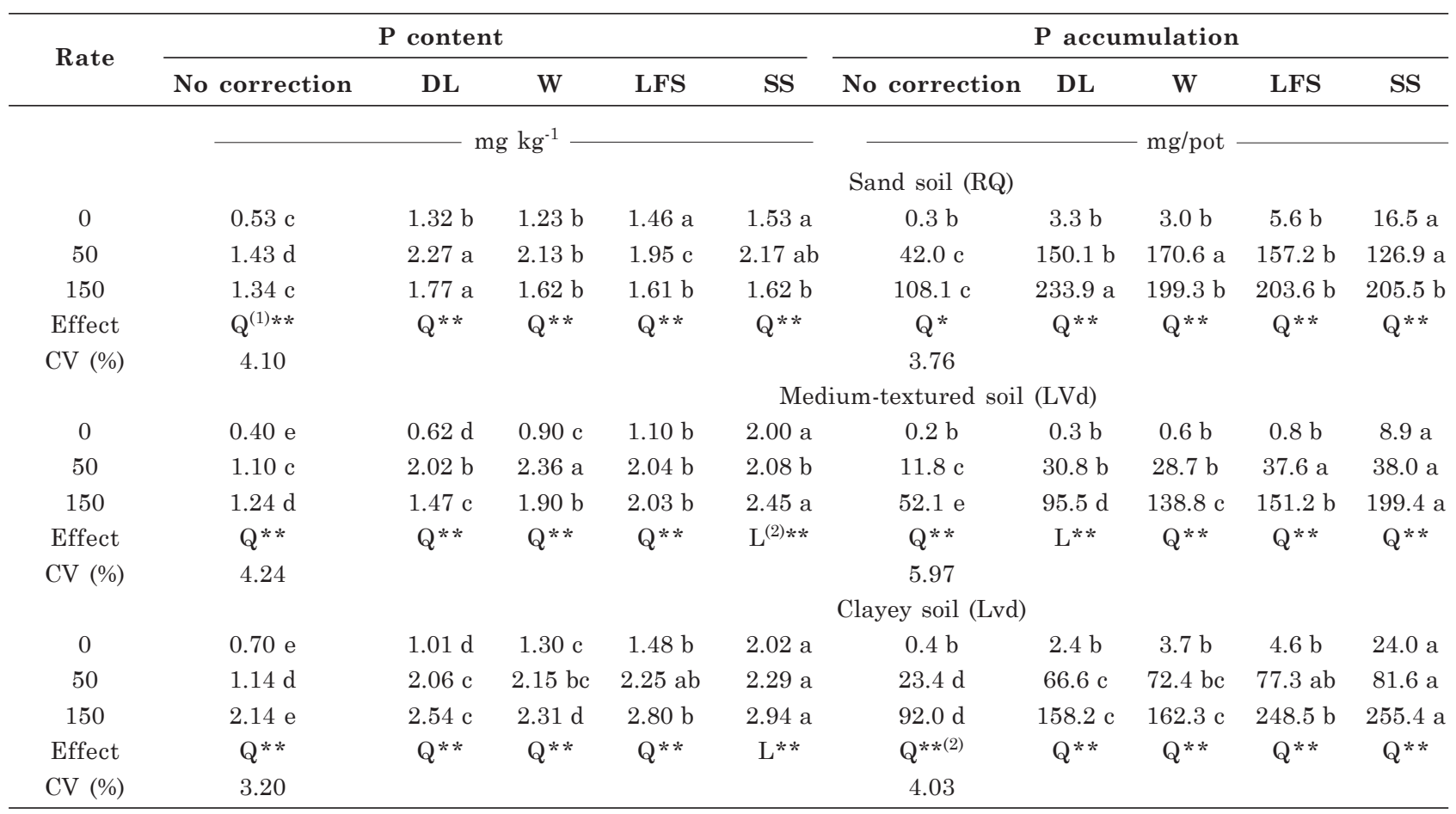

(1) Q: quadratic effect; ${ }^{(2)}$ L: linear effect. Lvd: dystroferric Rhodic Hapludox (Oxisols); LVd: dystrophic Rhodic Hapludox (Oxisols); RQ: dystrophic Typic Quartzipsamment (Entisol). Means followed by lower case letters in the same row differ statistically by Tukey's test at $1 \% .{ }^{*}$ and ${ }^{* *}$ significant at 5 and $1 \%$, respectively.

Table 6. Dry matter mass of corn plants according to corrective application and $\mathrm{P}$ rates in soils

\begin{tabular}{|c|c|c|c|c|c|}
\hline \multirow{2}{*}{ Rate } & \multicolumn{5}{|c|}{ Dry matter mass } \\
\hline & No correction & Dolomitic lime & Wollastonite & Ladle furnace slag & Steelmaking slag \\
\hline & & & Sand soil (RQ) & & \\
\hline 0 & $0.52 \mathrm{c}$ & $2.48 \mathrm{bc}$ & $2.42 \mathrm{bc}$ & $3.86 \mathrm{~b}$ & $10.74 \mathrm{a}$ \\
\hline 50 & $29.30 \mathrm{~d}$ & $66.28 \mathrm{~b}$ & $80.22 \mathrm{a}$ & $80.74 \mathrm{a}$ & $58.40 \mathrm{c}$ \\
\hline 150 & $80.66 \mathrm{~d}$ & $132.32 \mathrm{a}$ & $123.42 \mathrm{c}$ & $126.44 \mathrm{~b}$ & $126.90 \mathrm{~b}$ \\
\hline Effect & $\mathrm{Q}^{(1) *}$ & $\mathrm{Q}^{* *}$ & $Q^{* *}$ & $Q^{* *}$ & $\mathrm{Q}^{* *}$ \\
\hline \multirow[t]{2}{*}{ CV (\%) } & 2.15 & & & & \\
\hline & \multicolumn{5}{|c|}{ Medium-textured soil (LVd) } \\
\hline 0 & $0.52 \mathrm{~b}$ & $0.58 \mathrm{~b}$ & $0.70 \mathrm{~b}$ & $0.70 \mathrm{~b}$ & $4.46 \mathrm{a}$ \\
\hline 50 & $10.68 d$ & $15.30 \mathrm{~b}$ & $12.18 \mathrm{c}$ & $18.44 \mathrm{a}$ & $18.32 \mathrm{a}$ \\
\hline 150 & $42.10 \mathrm{~d}$ & $64.82 \mathrm{c}$ & $73.32 \mathrm{~b}$ & $74.68 \mathrm{~b}$ & $81.50 \mathrm{a}$ \\
\hline Effect & $\mathrm{Q}^{* *}$ & $\mathrm{Q}^{* *}$ & $Q^{* *}$ & $Q^{* *}$ & $\mathrm{Q}^{* *}$ \\
\hline \multirow[t]{2}{*}{ CV (\%) } & 4.61 & & & & \\
\hline & \multicolumn{5}{|c|}{ Clayey soil (Lvd) } \\
\hline 0 & $0.58 \mathrm{c}$ & $2.40 \mathrm{bc}$ & $2.82 \mathrm{~b}$ & $3.08 \mathrm{~b}$ & $11.90 \mathrm{a}$ \\
\hline 50 & $20.54 \mathrm{~d}$ & $32.30 \mathrm{c}$ & $33.74 \mathrm{bc}$ & $35.68 \mathrm{~b}$ & $40.72 \mathrm{a}$ \\
\hline 150 & $42.98 \mathrm{~d}$ & $62.44 \mathrm{c}$ & $70.26 \mathrm{~b}$ & $86.96 \mathrm{a}$ & $88.70 \mathrm{a}$ \\
\hline Effect & $\mathrm{Q}^{* *}$ & $Q^{* *}$ & $Q^{* *}$ & $Q^{* *}$ & $\mathrm{Q}^{* *}$ \\
\hline CV (\%) & 3.14 & & & & \\
\hline
\end{tabular}

(1) Q: quadratic effect. Lvd: dystroferric Rhodic Hapludox (Oxisols); LVd: dystrophic Rhodic Hapludox (Oxisols); RQ: dystrophic Typic Quartzipsamment (Entisol). Means followed by lower case letters in the same row differ statistically by Tukey's test at $1 \%$. ${ }^{*}$ and $* *$ significant at 5 and $1 \%$, respectively. 
fertilizers, Büll et al. (1997) observed that plants treated with powder magnesium thermophosphate had highest leaf P content, which was statistically superior to the other sources, and was attributed to Si in this phosphate fertilizer.

It was observed that, similarly to $\mathrm{P}$ content, $\mathrm{P}$ accumulation was highest for all soils when steelmaking slag was used, even when no $P$ was applied. It was noted that the $\mathrm{P}$ amount provided by this corrective $\left(0.74,2.18\right.$ and $2.24 \mathrm{mg} \mathrm{dm}^{-3}$ for sandy, medium texture and clayey soils, respectively) influenced the treatments.

Shoot dry matter P accumulation in the clayey soil had higher average values than in the other soils; accumulation was highest in the treatment with the highest $\mathrm{P}$ rate under steelmaking slag application. Concurrently, it was also noted that steelmaking slag, both in this as in medium-textured soil, promoted highest accumulation values at all applied $\mathrm{P}$ rates, which can be attributed to the favorable effect of silicate and phosphate competition for the same soil adsorption sites.

The interaction between $\mathrm{P}$ rates and correctives influenced the shoot dry matter, which varied according to soil, $\mathrm{P}$ rate, and corrective source (Table 6). It can be noted that in all studied soils the application of $\mathrm{P}$ significantly influenced shoot dry matter production, fitting a quadratic polynomial model for all sources of corrective materials.

Regarding corrective sources, slags provided similar results, but when lime was used, there was a greater accumulation of shoot dry matter (132.32 g) at the highest $\mathrm{P}$ rate. However, it was observed that when no $\mathrm{P}$ was applied to the soil, steelmaking slag induced a very high dry matter production (11.90 g) but lime only $0.52 \mathrm{~g}$.

\section{CONCLUSIONS}

1. Slags increased $P$ content in the soil compared to lime, suggesting a positive interaction between $\mathrm{Si}$ and $\mathrm{P}$ within the soil.

2 . The use of silicon does not interfere with extractor choice, since both Mehlich-1 and resin performed similarly in relation to $P$.

3. For all analyzed plant parameters, there was a significant interaction between $P$ rates and correctives, with highest values under silicate application.

\section{LITERATURE CITED}

ALCARDE, J.C. Metodologia oficial de análise de corretivos de acidez. Porto Alegre, Genesis, 2009. 58p.
ALVAREZ V., V.H.; NOVAIS, R.F.; DIAS, L.E. \& OLIVEIRA, J.A. Determinação e uso do fósforo remanescente. Bol. Inf. Soc. Bras. Ci. Solo, 25:27-32, 2000.

ASSIS, M.H.S.; PEREIRA, H.S.; BARBOSA, N.C.; CARNEIRO, M.A.C. \& PAIVA, J.B. Formas de aplicação de fertilizante silicatado e seus efeitos no solo e na produção de sorgo. In: CONGRESSO BRASILEIRO DE CIÊNCIA DO SOLO, 31., 2007, Gramado. Anais... Gramado: SBCS, 2007. CDROM

BRITO NETO, J.F. Adsorção e disponibilidade de fósforo para o crescimento inicial de mamoneira em solos com diferentes classes texturais. Botucatu, Universidade Estadual Paulista, 2011. 82p. (Dissertação de Mestrado)

BÜLL, L.T.; LACERDA, S. \& NAKAGAWA, J. Termofosfato: alterações em propriedades químicas em um Latossolo Vermelho-Escuro e eficiência agronômica. Bragantia, 56:169-79, 1997.

CAMARGO, A.B. Escória de Siderurgia e a nutrição fosfatada de milho inoculado com gunfos micorrízicos arbusculares. Seropédica, Universidade Rural do Rio de Janeiro, 2009. 63p. (Dissertação de Mestrado)

CAMPELLO, M.R.; NOVAIS, R.F.; FERNÁNDEZ, R.I.E.; FONTES, M.P.F. \& BARROS, N.F. Avaliação da reversibilidade de fósforo não-lábil para lábil em solos com diferentes características. R. Bras. Ci. Solo, 18:157$165,1994$.

CARVALHO, R.; FURTINI NETO, A.E.; CURI, N.; FERNANDES, L.A. \& OLIVEIRA JUNIOR, A.C. Dessorção de fósforo por silício em solos cultivados com eucalipto. R. Bras. Ci. Solo, 24:69-74, 2000.

EMPRESA BRASILEIRA DE PESQUISA AGROPECUÁRIA EMBRAPA. Centro Nacional de Pesquisa de Solos. Sistema brasileiro de classificação de solos. 2.ed. Rio de Janeiro, 2006. 306p.

ERNANI, P.R.; FIGUEIREDO, O.R.A.; BECEGATO, V. \& ALMEIDA, J.A. Decréscimo da retenção de fósforo pelo aumento do pH. R. Bras. Ci. Solo, 20:159-162, 1996.

DEUS, A.C.F. Avaliação de eficiência relativa para a reatividade em silicatos. Botucatu, Universidade Estadual Paulista, 2010. 129p. (Dissertação de Mestrado)

GONÇALVES, J.L.M.; FIRME, D.J.; NOVAIS, R.F. \& RIBEIRO, A.C. Cinética de adsorção de fósforo em solos de Cerrado. R. Bras. Ci. Solo, 9:107-111, 1985.

MALAVOLTA, E.; VITTI, G.C. \& OLIVEIRA, S.A. Avaliação do estado nutricional das plantas: princípios e aplicações. 2. ed. Piracicaba, Potafos, 1997. 319 p.

MUNIZ, A.S.; NOVAIS, R.F.; FREIRE, J.M.; NEVES, J.C.L. \& BARROS, N.F. Disponibilidade de fósforo e recomendação de adubação avaliadas por meio de extratores químicos e do crescimento de soja em amostras de solo com diferentes valores do fator capacidade. R. Ceres, 34:125-151, 1987.

NOVAIS, R.F. \& KAMPRATH, E.J. Fósforo recuperado em três extratores químicos como função de fósforo aplicado no solo e do "fator capacidade". R. Bras. Ci. Solo, 3:37-41, 1979 . 
NOVAIS, R.F.; SMYTH, T.J. \& NUNES, F.N. Fósforo. In: NOVAIS, R.F.; ALVAREZ V., V.H.; BARROS, N.F.; FONTES, R.L.F.; CANTARUTTI, R.B. \& NEVES, J.C.L., eds. Fertilidade do solo. Viçosa, MG, Sociedade Brasileira de Ciência do Solo, 2007. p.276-374.

NOVELINO, J.O.; NOVAIS, R.F.; NEVES, J.C.L.; COSTA, L.M. \& BARROS, N.F. Solubilização de fosfato de Araxá, em diferentes tempos de incubação, com amostras de cinco Latossolos, na presença e na ausência de calagem. R. Bras. Ci. Solo, 9:13-22, 1985.

OBIHARA, C.H. \& RUSSEL, E.W. Specific adsorption of silicate and phosphate by soils. J. Soil. Sci., 23:105-107, 1972.

RAIJ, B.van; ANDRADE, J.C.; CANTARELLA, H. \& QUAGGIO, J.A. Análise química para avaliação da fertilidade de solos tropicais. Campinas, Instituto Agronômico de Campinas, 2001. 284p.

RAIJ, B.van.; CANTARELLA, H.; QUAGGIO, J.A. \& FURLANI, A.M.C. Recomendação de adubação e calagem para o estado do São Paulo. 2.ed. Campinas, Instituto Agronômico \& Fundação IAC, 1996. 285p.

RAIJ, B.van. Seleção de métodos de laboratório para avaliar a disponibilidade de fósforo em solos. R. Bras. Ci. Solo, 2:19, 1978.
ROY, A.C.; ALI, M.V.; FOX, R.L. \& SILVA, J.A. Influence of calcium silicate on phosphate solubility and availability in Hawaian Latosols. In: SYMPOSIUM ON SOIL FERTILITY AND EVAlUATION, 1971, New Delhi. Proceedings... New Delhi, University of Hawaii, 1971. p.756-765.

SCHLINDWEIN, J.A. \& GIANELLO, C. Calibração de métodos de determinação de fósforo em solos cultivados sob sistema de plantio direto. R. Bras. Ci. Solo, 32:2037-2049, 2008.

SILVA, J.T.A. \& BRAGA, J.M. Sensibilidade de extintores de fósforo e nível crítico de dez solos do Estado de Minas Gerais. R. Ceres, 39:542-53, 1992.

TEDESCO, M.J.; GIANELLO, C.; BISSANI, C.A.; BOHNEN, H. \& VOLKWEISS, S.J. Análise de solo, plantas e outros materiais. 2.ed. Porto Alegre, Universidade Federal do Rio Grande do Sul, 1995. 174p. (Boletim Técnico, 5)

VASCONCELLOS, C.A.; BRAGA, J.M.; NOVAIS, R.F. \& PINTO, O.C.B. Fósforo em dois Latossolos do Estado de Mato Grosso: I. Sorção de fosfato. Experientae, 18:267285, 1974.

VOLKWEISS, S.J. \& RAIJ, B.van. Retenção e disponibilidade de fósforo em solos. In: SIMPÓSIO SOBRE O CERRADO, 4., 1977, Belo Horizonte. Anais... Belo Horizonte, Itatiaia, 1977. p.317-332. 